\title{
Decisions made on the Development of the Hill Station of Cameron Highlands from 1884 till present day
}

\author{
Robert C.M. Weebers ${ }^{1} \&$ Hanizah Idris $^{2}$ \\ Faculty of Arts and Social Sciences, Department of Southeast Asian Studies, Universiti of Malaya, Malaysia. \\ ${ }^{1}$ robertcmweebers@gmail.com, \& $\underline{2}$ wafa@um.edu.my
}

\begin{abstract}
The aim of this paper is to show which decisions were taken to direct the development of Cameron Highlands with regard to the usage of the area from 1884 till the present day. Is the character of Cameron Highlands maintained as a hill station for relaxation and health as intended by the British or does the development take another direction. The development of Cameron Highlands is well planned and organized by the British. The hill station is meant to be a sanatorium, for relaxation, amusement and agriculture (tea plantations and vegetable farms). Decisions are made on the construction of roads, the lay-out of the area, distribution of land for residential or agricultural use, on the establishment of townships and the erection of buildings. Present day development of Cameron Highlands is linked to tourism (agro-tourism, eco-tourism and cultural and heritage tourism). In the last years a dramatic increase in the development in Cameron Highlands takes place where areas of forests are cleared for vegetable and flower growing as well as for housing development. This has resulted in soil erosion problems, siltation of lakes and rivers. There is an urgent need for conservation, agriculture, watershed protection and resort development.
\end{abstract}

Keywords: Hill stations, Mainland Southeast Asia, Peninsular Malaya, Cameron Highlands.

\section{INTRODUCTION}

William Cameron is hired by the British Government, in 1885, to survey areas in Perak, Pahang and Selangor. Cameron comes close to the area nowadays known as Cameron Highlands but never to the area itself. The initiative to develop Cameron Highlands is taken by Sir George (William) Maxwell. Investigations of the area are conducted in a thorough way. Surveys are carried out to establish which parts of Cameron Highlands can be suitable for what use. Decisions are thought out and discussed. Access to the area is needed to be able to begin development. Construction of roads is undertaken.

Several expeditions (1922 and 1925) are organised which include experts on geology, botany and health. The outcome of the investigations is Cameron Highlands is suited for a hill station with a sanatorium. A Development Committee is appointed in 1925 which decided how the area will be developed. Consecutive High Commissioners, Sir Laurence Nunns Guillemard, Sir Cecil Clementi and Sir Shenton Whitelegge Thomas give direction to the development of Cameron Highlands. 
The decisions on the development of Cameron Highlands involve usage of areas, the establishment of town lets and buildings.

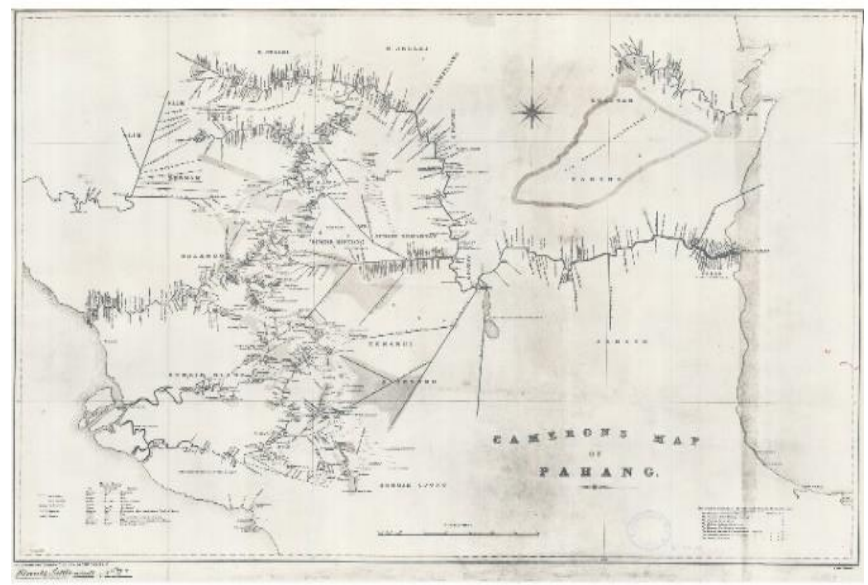

Figure 1: Cameron's Map of Pahang (Straits 21) 1889

Courtesy of the National Archives of Malaysia

The area is designated as a holiday resort and as a district administrative centre for planting and residential purposes. The town of Tanah Rata is established in the Hill Station of Cameron Highlands in 1931 when the Cameron Highlands Development Committee on the rezoning of the Northern Highlands decide a township site will be appointed including post office, police station and local administrative offices. (Report of the Cameron Highlands Development Committee on the re-zoning of the Northern Highlands,1931).

The important aspect of the development of Cameron Highlands is that it is developed as a retreat for the British in Malaya with all the characteristics, attractions and facilities of the home country. These are climate, clubs, golf courses, racecourses, lakes, architecture (government buildings, country houses, bungalows and churches), botanical gardens, vegetation (plants and flowers) and life style. Almost everything in a hill station is a duplication of the home country. In Cameron Highlands buildings are designed in the English Tudor Revival style and the black-andwhite Tudor Revival style. Characteristic for Cameron Highlands is agriculture (vegetable farms) and tea plantations like the Cameron Bharat plantation and the Sungai Palas Boh plantation.

\section{METHODOLOGY}

The study is based on content analysis. Interpretations based on documents and literature on the choices made for the development of Cameron Highlands. The documents were found in the records in the National Archives of Malaysia supported by literature (books and articles) on Cameron Highlands. These include Annual Reports, Budget proposals, Guidelines on the development of Cameron Highlands, Memoranda, Minutes of meetings, Reports of visits by the Chief Secretary of the Federated Malay States, Reports by a Health Commission and records with regard 
to the construction of buildings and on the construction of roads. Literature studied on the history of Cameron Highlands included: Books: Hecke, S. van \& Linde, L. van der (2011) and Moore, W.K. (2004). Articles: Scrivenor J. B. (1931) and Maxwell W. G. (1926).

\section{DECISIONS ON THE DEVELOPMENT OF CAMERON HIGHLANDS}

In 1888 Sir Hugh Low shows interest to develop Cameron Highlands as a hill station. In a minute dated 29th of September 1888 Low advises that a good sanatorium should be found in Cameron Highlands. (No. 13 of 1925 Federated Malay States, 1925). Low points out that the place is near the pass into Pahang to which a cart road is constructed. To support this proposal Low asks for a report from the State Engineer F. St. G. Caulfeild The report is submitted on the $10^{\text {th }}$ of November 1888. Caulfeild surveys an area "with a size of sixty thousand to a hundred thousand acres. The valleys run nearly east and west so that both slopes catch the morning sun, and the soil, judging from the small portion explored, is of excellent quality. The temperature in the valleys is mild and equable, the warm air retained between the ridges prevents those rapid and dangerous changes which occur on our mountain tops. This country will be brought within easy reach of invalids by the Tapa-Pahang car road, now in course of construction” (No. 13 of 1925 Federated Malay States, 1925).

From 1888 till 1905 roads are constructed to develop areas in Perak for agricultural purposes and for access in Pahang territory. Work on a cart road from Tapah to Pahang Pass is started. Work is stopped on the roads in 1905. The financial crisis in 1920 prevents any further discussion of road programmes and the programmes are put on hold till 1922. (No. 13 of 1925 Federated Malay States,1925).

Maxwell initiates again, in 1922, the issue of establishing a new hill station. He arranges an expedition into Cameron Highlands, the area surveyed by Caulfeild in 1888, to decide how to develop the area. The British Government is looking for an area for vegetable growing and to reduce dependence on neighbouring countries and to create another hill station. (Hecke, S. van \& Linde, L. van de, 2011) The expedition is led by H.C. Robinson. Included in the expedition are experts on geology, botany and malaria.

In 1925 another expedition is organized into Cameron Highlands. Maxwell visits the area with a party of experts. The reports of the experts of the previous expedition of 1922 are used to support the decision to develop Cameron Highlands. This expedition includes experts on agriculture and again on health. It is decided to develop the area in a Hill station. (No. 13 of 1925 Federated Malay States,1925).

The next step is the appointment of a Committee which is to advise on the development of Cameron Highlands. Maxwell, remarks, in his report of the $11^{\text {th }}$ of April 1925, it is of great importance the lay-out of the place be started and continued on sound principles. The Committee will have to include the Government Town Planner as Chairman, the Surveyor-General, the Director of Public works and the Chief Secretary of the Federated Malay States as 
members. The first points to decide upon by the Committee will be the area and extent of the area to be appropriated for the Admiralty, the War Office and the Air Ministry. Vegetables such a potatoes, cabbages, tomatoes etc. can be grown on a commercial scale. For the time being no applications for land above the Robinson Fall will be considered. The government has to decide which area will be reserved for residential purposes and then consider applications for land or planting purposes outside this area (No. 13 of 1925 Federated Malay States,1925). Maxwell focuses on Cameron Highlands as a holiday destination.

The Cameron Highlands Development Committee gives a direction for the development of Cameron Highlands at the first meeting on the $18^{\text {th }}$ of May 1926. The Committee passes the following resolutions: "That no applications for either residential areas or for agriculture should be accepted for any part of the area, either in Cameron Highlands proper or in the valleys of the Ringlet and Habu, until the general policy and lines of development of the Highlands are settled and the question of naval and military areas decided". "That even when matters are settled, it may be advisable not to accept any applications for residential areas for agriculture until road access is available to the vicinity of the areas applied for" (Chronicle of the Development of the Cameron Highlands during the period in which it was directed and supervised by the Cameron Highlands Development Committee (1926-1931),1932).

In the following years discussions are held, decisions are made and memoranda written on the establishment of villages, townships, on the alienation of land and the construction of houses and roads.

In 1926 at a Resident's Conference on the development of Cameron Highlands on the $7^{\text {th }}$ September 1926, at the Residence of the High Commissioner, Sir Laurence Nunns Guillemard, Carcosa in Kuala Lumpur more decisions are taken with regard to Cameron Highlands. There will be no Federal Capital at the Highlands, the Committee will have the power to overrule decisions by the Government, in respect to the lay-out the aim will be to develop the Highlands as a holiday station and a health resort and all applications for land must be dealt with through the Residents of the State concerned acting on the advice of the Committee.

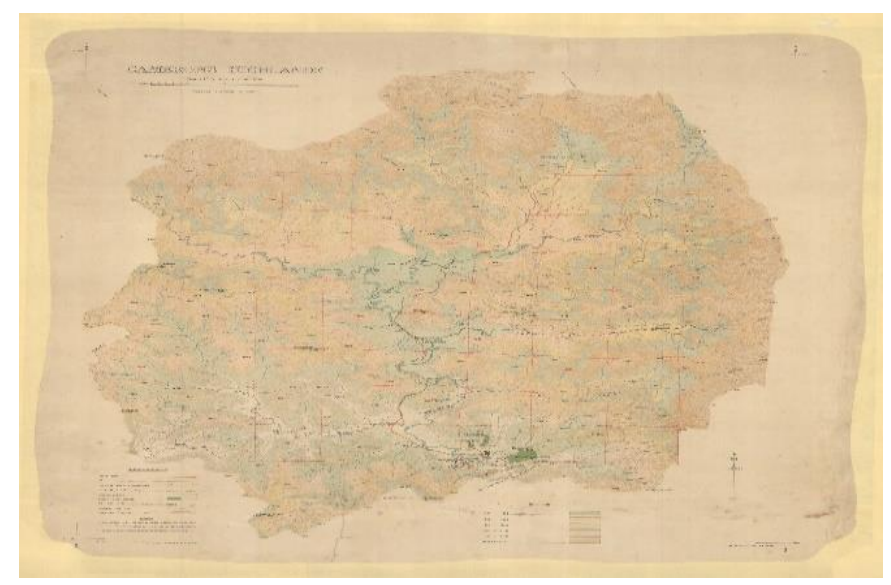

Figure 2: Cameron Highlands 1928

Courtesy of the National Archives of Malaysia 
The Hill station is to contain a serviceable area for the Air force, Navy and Military, no special territory will be under the jurisdiction of the Government, provision will be made for a small township site, an ample area adequate to the needs of a holiday resort will be reserved for recreation and viewpoints will be established for the public. The ideas with regard to the lay-outs of Baguio (Philippines) and Nuwara Eliya (Sri Lanka) have to be implemented. One of the features of Nuwara Eliya is the open spaces devoted to golf, polo, racecourse and recreation (Memorandum on the Guiding Principles of Policy,1929). In an informal meeting of Thursday $6^{\text {th }}$ of August 1931 of the Highlands Development Committee a township site is discussed including hospital, post office, police station and local administrative offices. This meeting is presided by the High Commissioner Sir Cecil Clementi (Minutes of an Informal Meeting at the Cameron Highlands Development Committee,1931). Clementi focuses on Cameron Highlands as a holiday destination and agricultural area. In Clementi's plan the steep slopes of the area are going to be used for farming, which according to the Cameron Highlands Development Committee, will lead to erosion (Freeman, 1999).

In 1934 Sir Shenton Whitelegge Thomas instructs an area will be reserved for a Botanical Garden. In the garden trees, shrubs, flowers etc. will be grown common in the Highlands. There will also be a road, lawns, a children playground, a small museum in which specimens of various timbers and plants can be displayed etc. The area will be too far from the inhabited area. Some facilities for water should be available (Cameron Highlands 1) National Park 2) Botanical Garden 1934,1934).

In the $83^{\text {rd }}$ conference of residents, in 1939, the future policy of the Development of Cameron Highlands is discussed. The Highlands will not be developed as a holiday resort, but as a District administrative centre for planting and residential purposes as well, with suitable accommodation for the Naval, Military and Air Forces, a village and other associated facilities and services. (Extract from the Minutes of the $83^{\text {rd }}$ Conference of Residents 1939,1939).

In 1941 in his Memorandum of $12^{\text {th }}$ of February 1941 C.C. Brown, the British Resident Pahang, notes there is no need to encourage for alienation of land. People are coming in great numbers. He thinks it is time to formulate a policy. Most of the applications are for building sites (Memorandum C.C. Brown British Resident Pahang, 12.02.1941).

In the meetings of 1941 of the Cameron Highlands Society discussions are held about wooden dwelling houses, alternative access and a riding track. A new private road is constructed up the Hubu Valley to the French Tekka power station and if a bridle track is constructed between these two so an alternative road will be created should the main road be blocked (Minutes of the Meeting of the Cameron Highlands Society at the Cameron Highlands Hotel on January $27^{\text {th }} 1941$ at 10.30 A.M., 1941). A road is to be constructed from the French Tekka power station to Ringlet due to the difficult nature of the country it cannot be considered. The possibility of making a riding track on the land reserved for an extension of the golf course is investigated but the matter is held up due to illness of the 
Executive Engineer. (Minutes of the Meeting of the Cameron Highlands Society In the Society's Office at Ringlet on May $21^{\text {st }} 1941$ at 10.30 A.M., 1941).

From 1942-1945, during the Japanese occupation, no development takes place in Cameron Highlands. Residents are allowed to continue their daily lives because the vegetable farms are important to the Japanese for their supplies. After the $2^{\text {nd }}$ World War the economic development of Cameron Highlands is undertaken. Focus is on the increase of vegetable production.

From 1948 till 1960 development halts during the Malayan Emergency. The main issue of the insurgents is to destabilize Malaya and economic targets like mines and plantations are under attack and therefor under guard by the Government. The withdrawal of Japan at the end of the Second World War leaves the Malayan economy disrupted.

Before independence, in 1957, the role of the Cameron Highlands Development Committee, the Cameron Highlands Society Committee, the residents and the High Commissioners is to develop the area on a modest scale with in mind the to use the area as a sanatorium and for relaxation. Decisions are made by whom the land will be used and for whom the land is designated, about the lay-out of the area, about the establishment of the recreation areas (riding track, golf course), about daily issues of constructing buildings and a PowerStation or roads. Benefits of the development before 1957 is no massive development took place to maintain the character of the area as initially planned by the British.

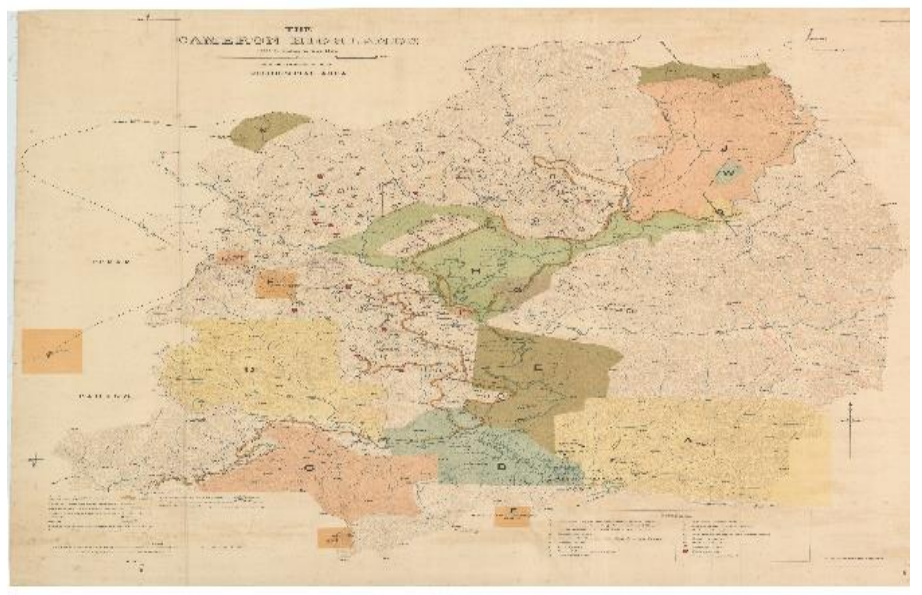

Figure 3: Cameron Highlands 1931

Courtesy of the National Archives of Malaysia

After independence, in 1960, a Cameron Highlands Tourist Association is formed to promote Cameron Highlands as a tourist destination. In the meetings from 1960 till 1963 plans are discussed to attract more tourists to Cameron Highlands. The plans include an artificial lake north of Ringlet with facilities for water skiing, speed boating and 
other water sports. A new road will be constructed on top of the adjoining hills. The present road from Ringlet to Tanah Rata will be abandoned. New hotels are planned. A Halting Station will be built with facilities on top of the 5,565 feet high Gunong Jasa for climbing, The cultural background of the Aborigines will be shown with dances and arts and crafts. More view points will be established. A promenade is planned outside Tanah Rata. There is a proposal for an air service by Aviation Services (Malaysia) Ltd. An agricultural show is going to be organised. (Minutes of the Meeting of the Board of the Cameron Highlands Tourist Promotion Association held at the Town Board Office 1960-1963)

In the British area, Cameron Highlands is known for its cool climate and scenic landscapes. The highland serves British government officials as a retreat, providing relief from the tropical climate. Development is tightly controlled. Farmers get allocated small parcels of land. After Malaysian independence the highland is promoted as a tourist destination. Massive land clearing takes place. At the same time, more agricultural land is developed into resorts and since the 1970's many vacation homes and hotels are built in the area. The District Council and the Land Office of Cameron Highlands are the agencies responsible for the management of the highland. Although both agencies are conscientious in the management tasks, differences in policy or regulation sometimes create overlapping duties or conflicts over specific methods and strategies. The economic growth of the

Cameron Highlands is based on agriculture and tourism. Analysis shows agriculture has the major land use, focusing primarily on tea plantations and vegetable farms. However, tourism and the cut flower industry have economic importance as well. These uses have dominated the pattern of land use since the 1930's suggesting the landscape management practices of the Cameron Highlands have produced diversities of land use. Among these uses, however, maintaining natural areas (e.g. forest, hill, waterfall and lake) probably has the most significant impact on tourism. Even during colonial times the importance of the Cameron Highlands as a natural area is recognized, although the land is used for tea plantations. The tourism industry is still flourishing here, and even increasing. The tourism industry of the Cameron Highlands has great potential to expand and draw tourists from around the world (Othman, 2011).

Present day development of Cameron Highlands is linked to three kinds of tourism. In the Cameron Highlands Development Plan 2003-2015 tourism focuses on agro-tourism, eco-tourism and cultural and heritage tourism (Hosni and Shinozaki, 2007). The main form of land use is agriculture, with over 2,500 hectares of tea plantations and vegetable farming. There has been a dramatic increase in development in Cameron Highlands over the last 5 years where new areas of forests are cleared for vegetable and the flower growing as well as for housing development. This has resulted in massive soil erosion problems, the siltation of lakes and rivers as well as landslides. There is an urgent need for conservation, agriculture, watershed protection and resort development.

With regard to the development of Cameron Highlands in present times the opinion of a representative of the authorities and reaction to these by private persons is noteworthy. Assistant-Town planner Encik Suriesh 
Subramaniam of Cameron Highlands commented preservation of the area with the character of a hill station is an important issue with the authorities of Cameron Highlands. To preserve the character of Cameron Highlands the design of the buildings is kept in black and white and the building height is controlled. For apartments there is a maximum of $7 \frac{1}{2}$ stories and for shop lots there is maximum of 5 stories. The goal is to maintain the character of horticulture and service (hotels). Eco tourism is important: flower farms, tea plantations, jungle tracking and mossy forest. Changes take place in the quality of the ecosystem because of the massive development with no control over vegetable and flower growing. In present day times farms change from vegetables to flower growing without approval. In the process illegal structures are demolished and crops destroyed. The Forest Reserve is getting less and the water quality is getting worse (Subramaniam, Suriesh, Personal interview, 16 June, 2014). Encik Kok See Shan, Curator Time Tunnel Museum, is not satisfied with developments in Cameron Highlands. Nowadays land is cleared illegally, land which belongs to Forest Reserve is cut down and land is used without approval for vegetable growing (Kok, See Shan, Personal interview, 17 June 2014).

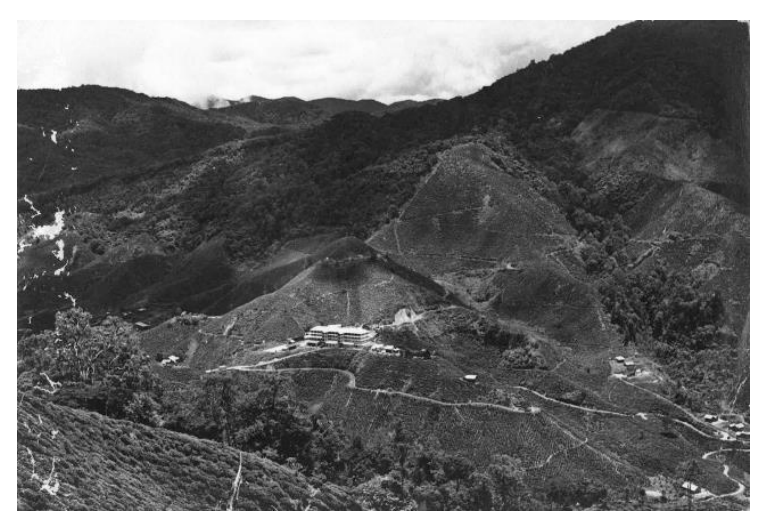

Figure 4: Tea Plantation. Year unknown

Courtesy of the National Archives of Malaysia

No lessons are learned in present times with regard to clearing of the land and subsequent erosion of the soil and landslides. The policy of encouraging more agriculture and developing more resorts for tourism and recreation will, in time, lead to an increase of the environmental problems of Cameron Highlands. The flat and gently sloping land in Cameron Highlands is limited and most of the land is already used. Any new development will take place on the steep slopes. Any construction on steep land in an area with heavy rainfall, such as in Cameron Highland will result in soil erosion when the protective vegetation is removed. Visiting tourists cannot be housed because of a lack of accommodation. Alternative accommodation is offered by an increasing number of holiday homes catering to companies or wealthy individuals. To be able to meet the demand for more accommodation use is made of the steeper slopes due to the limited amount of flat land available for residential purposes. The production of vegetables and flowers grow in cooler climates has increased. Use is made, as well, of the steep slopes to meet the demand for more farms. Many environmental problems arise because farms are located on precipitous slopes and within water catchment areas. Inappropriate developing methods add to these problems with the use of heavy machinery, 
excessive cutting and filling of land. Control and enforcing regulations to reduce the severity of the methods of developing lack. The plans for highways linking the hill resorts of Genting Highlands, Fraser's Hill and Cameron Highlands will result in another wave of developing resorts with a considerable stress on the environment. An ecological appropriate plan is needed. The plan will balance the needs for tourism and recreation, scientific, education and conservation functions as well as cater for agricultural development (Leong, Y.K. 1992).

\section{CONCLUSION}

The initial idea is to develop Cameron Highlands as a retreat for relaxation and health. The hill station has all the characteristics of the British home country (climate, clubs, golf courses, racecourses, lakes, architecture (government buildings, country houses, bungalows and churches), botanical gardens, vegetation (plants and flowers) and life style. The development before independence is controlled and kept in check. Decisions are made to maintain the character of the hill station as meant by the British. Land is distributed for agriculture use on a limited base. After 1957 development of the area takes a leap forward. Facilities are created to attract more tourists. Agriculture is expanded and land is cleared to build farms. The usage of the flat land is limited, to expand the steep slopes of the area have to be used. The land clearing leads to erosion of the soil. With as a result massive landslides. No lessons are learnt from previous development plans. In present times the authorities maintain the character of the hill station with the characteristic black and white design of the buildings and attract tourists through eco-tourism (flower farms, tea plantations, jungle tracking and mossy forest). Agriculture is expanding beyond the control of the authorities. The character of Cameron Highlands as a retreat for relaxation and holiday, as intended by the British should be maintained, without an overpowering presence of agriculture. The authorities should develop and submit a plan to control the development of Cameron Highlands and implement this plan with stringency.

\section{REFERENCES}

Cameron, W. (1833-1886). British government surveyor.

Caulfeild, F. St. G., Perak State Engineer.

Clementi, C. (1875-1947). Governor and Commander-in-Chief of the Straits Settlements and High Commissioner for the Federated Malay States from 1929 to 1934.

Freeman, D. B. (1999). Hill stations or horticulture? Conflicting imperial visions of the Cameron Highlands. Malaysia Journal of Historical Geography, 25(1), 17-35.

Hecke, S. L. and Van der Linde L. (2011). Cameron Highlands discover the story (O. Neill M \& E. Barkhuizen Eds.). Skelmersdale, England: Copyrighthouse.

Hosni, N. and Shinozaki, M. (2009). Landscape Visual Classification Using Land Use and Contour Data for Tourism and Planning Decision Making in Cameron Highlands District. World Academy of Science, Engineering 
and Technology International Journal of Civil, Environmental, Structural, Construction and Architectural Engineering, 3 (6), 269-276.

Jamilah Othman. (2011). Scenic Beauty Preferences of Cameron Highlands Malaysia: Local versus Foreign Tourists. International Journal of Business and Social Science, 2(6), 248-253.

Kok, S. S., Curator Time Tunnel Museum, Cameron Highlands, Personal communication, June 17, 2014.

Leong, Y. K.. (1992). Conservation and Development of Cameron Highland, In R.P Lim \& Lee Sun Win (Eds.), Hill Development; Proceedings of the Seminar Malayan Nature Society, Kuala Lumpur (pp. 20-32).

Low, H. (1824-1905). British colonial administrator and naturalist and fourth Resident of Perak (1877-89).

Maxwel, W. G. (1926). Cameron's Highlands. Journal of the Malayan Branch of the Royal Asiatic Society, 4(1) (96), 122-128.

Maxwell, G. (1871-1959). Colonial administrator in British Malaya. Chief Secretary of the Federated Malay States from 1920-1926.

Moore, W.K. (2004). Malaysia: A Pictorial History 1400-2004. Kuala Lumpur, Malaysia: Archipelago Press. Nunns Guillemard, L. (1862-1951). British civil servant and diplomat. Appointed Governor of the Straits Settlements and British High Commissioner in Malaya in 1920, He left Malaysia in 1927 and retired from the diplomatic Service.

Robinson, H. C. (1874-1929) British zoologist and ornithologist. Director of Museums in Kuala Lumpur 1903 1926.

Scrivenor J. B. (1931). Recollections of Camerons's Highlands and Fraser's Hill. Journal of the Malayan Branch of the Royal Asiatic Society, 9 (1), 2-14.

Subramaniam, S. Assistant-Town planner, Cameron Highlands, Personal communication, June 16, 2014.

The National Archives of Malaysia. (1932). Chronicle of the Development of the Cameron Highlands during the period in which it was directed and supervised by the Cameron Highlands Development Committee (1926-1931) and the stage at to the development had arrived when the committee handed over control to the government of Pahang. 15th February 1932. Kuala Lumpur: Malaysia. Federated Malay States Government Printing Office. Ref. No: 1957/0274806.

The National Archives of Malaysia. (1925). No. 13 of 1925 Federated Malay States. Paper to be laid before Federal Council. Report by the C.S on a visit to Cameron's Highlands in March, 1925, while special reference to Communications with \& Development of The Highlands. Ref. No: 1957/0236123 
The National Archives of Malaysia. (1929). Memorandum on the Guiding Principles of Policy as enumerated by Government underlying the recommendations of the Camerons Highland Development Committee as to Zoning and Lay-out of the area within its jurisdiction, and the acceptance by Government of those recommendations as recorded in No. 19 of 1929 Federated Malay States. Ref. No: 1957/0303892.

The National Archives of Malaysia. (1931) Report of the Cameron Highlands Development Committee on the rezoning of the Northern Highlands (As considered at a special meeting held in Kuala Lumpur on the 27th April, 1931). Ref. No: $1957 / 0274806$.

The National Archives of Malaysia. (1934) Cameron Highlands 1) National Park 2) Botanical Garden 1934. Ref. No: $1957 / 0000936$

The National Archives of Malaysia. (1939). Extract from the Minutes of the 83rd Conference of Residents held at Carcosa on the 10th and 12th of September 1939. Ref. No: 1957/0303892.

The National Archives of Malaysia. (1939). Minutes of the Meeting of the Cameron Highlands Society.

Wednesday August 16th 1939 in the Cameron Highlands club at 10.30 A.M. Ref. No: 1957/05350222.

The National Archives of Malaysia. (1941). Minutes of the Meeting of the Cameron Highlands Society at the Cameron Highlands Hotel on January 27th 1941 at 10.30 A.M. Ref. No: 1957/05350222.

The National Archives of Malaysia. (1941). Minutes of the Meeting of the Cameron Highlands Society in the Society's Office at Ringlet on May 21st 1941 at 10.30 A.M . Ref. No: 1957/05350222.

The National Archives of Malaysia. (1949). Memorandum C.C. Brown British Resident Pahang 12.02.1941. Ref. No: $1957 / 0622829$.

The National Archives of Malaysia. (1960-1963). Minutes of the Meetings of the Board of the Cameron Highlands Tourist Promotion Association held at the Town Board Office 1960-1963. Ref. No: 1978/0005589.

The National Archives of Malaysia.(1931). Minutes of an Informal Meeting of the Cameron Highlands Development Committee to discuss the Zoning Proposals held at the Halting Bungalow at Tanah Rata at $2.15 \mathrm{pm}$ on Thursday 6th of August, 1931 under the presidency of his Excellency the High Commissioner for the Malay States. Ref. No: 1957/0271409.

Whitelegge Thomas, T. S. (1879-1962). Commonly known as Sir Shenton Thomas and the last Governor of the Straits Settlements from 1934 to 1942 